УАK 343.2-057.87

ББК 67.408 .06

DOI 10.22394/1682-2358-2017-2-87-93

M.Yu. Prilepskaya, postgraduate student of the Criminal and Penitentiary Law Department, Saratov State Academy of Law (email: prilepskaya2401@yandex.ru)

\section{COMPULSORY EDUCATIONAL MEASURES AND PENALTIES FOR MINORS}

Based on the analysis of scientific literature, current international standards and recommendations, and foreign legislation, the prospects of expanding the spectrum of response means for juvenile offenses are considered. Ways to improve the existing criminal penalties and compulsory educational measures in the Russian legislature are proposed.

Key words and word-combinations: minors, juvenile criminal law, compulsory educational measures, criminal sanctions.
М.Ю. Прилепская, аспирант кафедрьг уголовного и уголовно-исполнительного права Саратовской государственной юридической академии (email: prilepskaya2401@yandex.ru)

\section{ПРИНУАИТЕАЬНЫЕ МЕРЫ ВОСПИТАТЕ АЬНОГО ВОЗАЕЙСТВИЯ И НАКАЗАНИЯ В ОТНОШЕНИИ НЕСОВЕРШЕННОАЕТНИХ}

Аннотащия. На основе анализа научной литературы, зарубежного законодательства, существующих международных стандартов и рекомендаций рассматриваются перспективы расширения спектра средств реагирования на преступления несовершеннолетних. Предлагаются пути совершенствования имеющихся в российском законе уголовных наказаний и принудительных мер воспитательного воздействия.

Ключевые слова и словосочетания: несовершеннолетние, ювенальное уголовное право, принудительные меры воспитательного воздействия, уголовное наказание.

C нолетних и система борьбы с ней выступают важнейшими индикаторами развития общества и характеризуются некоторыми особенностями. С одной стороны, уровень указанной преступности остается относительно стабильным, что подтверждается, в частности, российскими статистическими

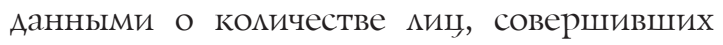
преступления в несовершеннолетнем возрасте. С Аругой стороны, характер и серьезность угроз от вовлеченности отмеченной 
возрастной группы в преступную деятельность требуют постоянного совершенствования имеющихся средств и поиска новых методов борьбы с преступмениями несовершеннолетних. Это находит прямое выражение в положениях уголовного закона и практике его применения.

В последние пять мет согласно офиџиальным данным МВА России количество миџ, совершивших преступления в несовершеннолетнем возрасте, демонстрирует устойчивую тенденцию к уменьшению: в 2010 г. - 78548 чел.; в 2011 г. - 71910 чел.; в 2012 г. - 64270 чел.; в 2013 г. -67225 чел.; в 2014 г. - 59549 чел.; в 2015 г. - 61833 человек. Тем не менее необходимость закрепления особого, в некотором смысле привилегированного уголовно-правового статуса несовершеннолетнего не оспаривается. Так, Уголовный кодекс РФ предусматривает освобождение несовершеннолетних как от угомовной ответственности, так и от наказания с применением принудительных мер воспитательного воздействия. ОАнако в рамках действуюшего российского законодательства уголовное наказание не явцяется единственной мерой реагирования на совершенное несовершеннолетним преступиение.

Указанного типа преступления имеют ряд криминологических особенностей, в числе которых пониженная общественная опасность мичности субъекта преступления, и это, в свою очереАь, влияет на специфику уголовной политики в отношении несовершеннолетних. Отметим, что акторы правовой политики применительно к совершенствованию положений уголовного закона в отношении несовершеннолетних постоянно находятся в поиске оптимального набора средств. Вектор такого поиска задан межАународными стандартами и объективными реалиями. Р.А. Колониченков полагает, что ювенальная уголовная политика в России базируется на следующих принципах:

1) «комплексносты мер профилактики, направленных на недопущение не только общественно опасных деяний, но и других антиобщественных действий (в контексте Федерального закона от 29 июня 2015 г. № 179-Ф3 «О6 основах системы профилактики правонарушений в Российской Федерации»);

2) приоритет воспитательных мер наА карательными, выражкающийся в осуществлении воспитательного процесса исправления при назначении мер уголовно-правового характера;

3) ресоциализация миџ, совершивших преступные деяния в несовершеннолетнем возрасте [1, с. 59-60].

Таким образом, акцент при проведении уголовной политики в отношении несовершеннолетних делается на работе с миџами, подвергшимися уголовному преследованию. ОАнако идеология борьбы с преступлениями несовершеннолетних определяется не чрезмерной миберальностью и гуманностью, негативно оцениваемыми видными специалистами по уголовному праву (например, А.И. Алексеевым, В.С. Овчинским, Э.Ф. Побегайло и Ар. [2, с. 90] ), а необходимостью ориентации мер ответственности несовершеннолетних на максимальный учет их мичностных особенностей в целях позитивных изменений в этой сфере [3, с. 200-202] .

А.В. Бельцов обоснованно указывает на отсутствие в российском уголовном законе каких-либо специальных наказаний дмя несовершеннолетних. В то же 
время в УК РФ устанавливаются «особые способы» их правового регулирования: ограничение круга наказаний, применяемых к несовершеннолетним; значительное сокращение объема кары по сравнению с содержанием таких же наказаний, применяемых по отношению к взрослым (за исключением наказания в виде мишения права заниматься определенной деятельностью, сроки назначения которого установлены ст. 47 УК РФ); ограничение применения наказания в виде кишения свободы по основаниям, установленным законом; предоставление суду возможности более широко применять к несовершеннолетним условное осуждение; возложение на родителей или иных законных представителей обязанности исполнить за несовершеннолетнего осужденного наказание в виде штрафа [4, с. 34]. Отмеченные особенности позволяют во многих случаях добиваться осуществления целей уголовной ответственности и наказания менее жесткими мерами, чем в аналогичных случаях в отношении взрослых. Таким образом, по словам И.А. Кобзаря, «...сушественно расширяются возможности индивидуализаџии и дифференциации ответственности и наказания несовершеннолетних преступников» [5, с. 158-159].

В научной китературе отмечается распространенная в России тенденџия назначения уголовного наказания несовершеннолетним в виде мишения свободы и условного осуждения [6, с. 90]. Рассмотрим в связи с этим перспективы применения ареста как вида наказания, связанного с краткосрочным мишением свободы, а также внеАрения эмементов пробаџии.

По мнению А.И. Бемяевой, арест в отношении несовершеннолетних неприемлем, полностью мишен педагогического смысла и явмяется самым жестким видом наказания, характер которого никак не может способствовать исправлению несовершеннолетнего [7]. ОАнако представляется, что именно арест мог бы стать крайней мерой в отношении несовершеннолетних преступников, применяемой краткосрочно, но с наибольшей эффективностью. Перспективным видится активное внеАрение эмементов пробаџии, выраженной в установленных законодательством мерах и санкциях, налагаемых на правонарушителя. В рамках этой процедуры предусматривается ряд мероприятий и правовых вмешательств, которые включают надзор, руководство и помощь, имеющие цемью соџиальную интеграџию правонарушителя, а также содействие обеспечению безопасности общества. Подробное описание этого института содержится в Рекомендаџии № Rec (2010) 1 Комитета министров Совета Европы «О Европейских правилах пробации». Важной ее составцяюшей является так называемая трудовая терапия, выраженная в выполнении обшественных работ. Воспитательные возможности трудовой терапии ставят на повестку дня вопрос о широком использовании обязательных и принудительных работ в качестве меры ответственности несовершеннолетних.

В уголовном законодательстве Российской Федерации для несовершеннолетних, совершивших преступление, предусмотрен специальный институт - принудительные меры воспитательного воздействия. Среди задач этого института - исправление, воспитание несовершеннолетнего, совершившего преступление, его позитивная соџиализаџия, формирование положительных навыков и привычек, предупреждение совершения им новых преступкений [8; 9]. 
Совершенно правы исследователи, считающие недопустимым сводить принудительные меры воспитательного воздействия к педагогическим [10; 11]. Не оспаривая факта направленности указанных мер на более широкое соџиальное воспитание, следует признать наличие в них репрессивной (карательной) составляющей в силу уголовно-правового характера [12]. Такого мнения придерживается Э.А. Биктимеров, считающий, что «...принудительные меры воспитательного воздействия представмяют собой меры госуАарственного принуждения, применяемые судом и оказывающие на несовершеннолетнего, совершившего преступление небольшой или средней тяжести, карательно-воспитательное воздействие, не явмяющееся уголовным наказанием» [13, с. 84] .

На наш взгляА, отечественному законодателю необходимо более интенсивно применять положительный опыт зарубежных стран, где меры воспитательного воздействия применяются эффективнее. Например, в ФРГ перечень мер воспитательного воздействия включает в себя обязанности соблюдать указания о месте пребывания, проживать в семье или в соџиальном учреждении, поступить на учебу или на работу, выполнять определенную работу, находиться поА руководством и набцюдением определенного киџа, принимать участие в курсе соџиального тренинга, в изучении правиц дорожного движения; обязанность примириться с потерпевшим и ряд Аругих. Заслуживает особого внимания одна из концептуальных идей немеџкого уголовного права - примирение с потерпевшим (\$46а УК ФРГ), применяемое также в ювенальном уголовном праве. Указанное действие закмючается в возмешении причиненного вреда полностью или в значительной части, Аибо в серьезном стремлении киџа возместить вреА, Аибо в возмещении ущерба в ситуации, когда это преАполагает значительные мичные затраты или мичный отказ от чего-Аибо [7] .

Во Франџии применение принудительных мер воспитательного воздействия регулируется специальным законом о несовершеннолетних - Ордонансом о правонарушениях несовершеннолетних от 2 февраля 1945 г. В перечень таких мер включаются передача родителям, опекуну, Аицу, под надзором которого он находияся, или мицу, достойному доверия; помещение в государственное или частное учебное или профессионально-техническое учреждение; помещение в медиџинское или медико-воспитательное учреждение; помешение в государственное воспитательно-исправительное учреждение; передача в службу помощи детству; передача в интернат дмя малолетних правонарушителей школьного возраста [14].

Анализ описанных мер показывает, что сочетание в них формальных и неформальных санкщий способствует гораздо большей эффективности. Согласно Рекомендаџии № $\operatorname{Rec}(2003) 20$ Комитета министров Совета Европы «О новых подходах к преступности среди несовершеннолетних и о значении правосудия по делам несовершеннолетних», «...Аля предупреждения совершения несовершеннолетними серьезных, насильственных и длительных преступлений государства-члены должны увеличивать спектр новаторских и более эффективных (но соразмерных) общественных санкций и мер, которые бы прямо учитывали преступное поведение и потребности преступника. При реализации данных санкџий и мер должны также привлекаться родители преступника 
или Аругой законный представитель (если это не окажкется непродуктивным), и по возможности предоставцяться защита, реститущия и возмещение вреАа потерпевшему» [15] .

В соответствии с ч. 2 ст. 90 УК РФ несовершеннолетнему могут быть назначены следующие принудительные меры воспитательного воздействия: преАупрежление; передача под надзор родителей или миџ, их заменяющих, мибо специализированного государственного органа; возможение обязанности загладить причиненный вред; ограничение досуга и установление особых требований к поведению несовершеннолетнего; помещение в специальное учебно-воспитательное учреждение закрытого типа. Аанные правоограниче-

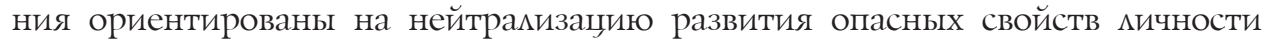
несовершеннолетнего и создание условий Аця благоприятного течения воспитательного процесса. Их следовало бы дополнить обязанностями пройти курс социально-психологического тренинга и проџедуру медиации, запретами контактов с определенными мицами, посещения определенных мест. К несовершеннолетним могут быть применены и такие меры безопасности, как принудительное мечение от алкоголизма или наркомании, наблюдение у врача, посещение специальных курсов психотерапии и иные мероприятия, способствующие нейтрахизации криминогенных свойств мичности и ее соџиальной адаптации [16, с. 193] .

Среди мер воспитательного воздействия в российском уголовном законе есть и мера восстановления - «обязанность загладить причиненный вреА». Н.В. ЩеАрин и Н.А. Никитина полагают, что предупреждение в текущей редакции ч. 1 ст. 91 УК РФ трудно отнести к мерам уголовно-правового характера. Поддерживаем мнение, что эта чисто воспитательная мера не содержит никаких ограничительных элементов; целесообразно исключить ее из перечня [17].

О степени эффективности принудительных мер уголовно-правового воздействия свидетельствует уровень рещидива среди миџ, на которых было направлено их применение. Анализ эффективности применения принудительных мер воспитательного воздействия следует проводить с учетом удельного веса общественно опасных деяний, совершенных подростками повторно посме их применения. ОАнако необходимо принимать во внимание, что имеющиеся низкие показатели рецидива частично объясняются применением мер воспитательного воздействия к той части подростков, которая совершает в массе своей незначительные преступления и не представцяет большой угрозы Амя общества $[13$, с. 128,131$]$.

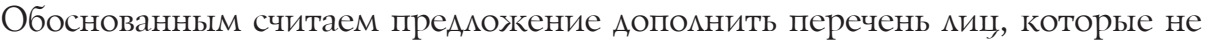
могут быть направлены в специальное учебно-воспитательное учреждение закрытого типа (согласно ч. 2 ст. 92 УК РФ), несовершеннолетними, являющимися организаторами преступлений, а также установить условия в виде неоднократного нарушения установценного распорядка, самовоцьного оставцения специального учебно-воспитательного учреждения закрытого типа, совершения административного правонарушения или преступления как основания Аля направления в суд ходатайства об отмене Аанного вида принудительных 
мер воспитательного воздействия и назначения наказания. Часто отсутствие в законодательстве порядка замены судом направления в специальное учебновоспитательное учреждение закрытого типа на наказание становится одной из основных причин указанных нарушений [18, с. 17].

Целесообразно разработать и принять ФеАеральный закон, регулирующий вопросы применения принудительных мер воспитательного воздействия и устанавливающий порядок взаимодействия органов государственной власти, местного самоуправления и общественных организаций в сфере воспитательного воздействия на несовершеннолетних правонарушителей. Необходимо законодательное закрепление комплексной юридической и педагогической характеристики содержания каждой принудительной меры воспитательного воздействия и выработанных практикой критериев индивидуализации ее применения [13, с. 134; 19].

Таким образом, международные стандарты и рекомендации, позитивный зарубежный опыт и объективные реалии явцяются факторами совершенствования российской системы наказаний и принудительных мер воспитательного воздействия в отношении несовершеннолетних. В первую очередь необходимо усилить профилактическую оставляющую и расширить спектр альтернативных наказанию мер ввиду их высокого исправительного потенциала, уголовноправовых мер, альтернативных мишению свободы. В силу педагогического соАержания они создают мучшие в сравнении с уголовным наказанием условия Аля развития положительных качеств мичности.

\section{Библиографический список}

1. Колониченков Р.А. Уголовная ответственность несовершеннолетних: вопросы законодательной регламентации и назначения наказания: дис. ... канд. юрид. наук. Ростов н/Д, 2009.

2. Попандопуло В.В. Преступность несовершеннолетних: состояние, функции, последствия, социальный контроль: автореф. дис. ... канд. юрид. наук. Краснодар, 2007.

3. Криминология: учебник / под ред. В.Н. Бурлакова, Н.М. Кропачева. СПб., 2002.

4. Бельияов Д.В. Уголовная ответственность за преступления несовершеннолетних и против несовершеннолетних: автореф. дис. ... канд. юрид. наук. Н. Новгород, 2008.

5. Кобзарь И.А. Уголовная ответственность и наказание несовершеннолетних по новому уголовному законодательству: дис. ... канд. юрид. наук. М., 1998.

6. Орлова Ю.Р. Некоторые проблемы реализации уголовной политики в отношении несовершеннолетних в условиях трансформации российского общества // Известия Тульского государственного университета. Экономические и юридические науки. 2014. № 1/2. С. 86-95.

7. Беляева Л.И. К вопросу об уголовной ответственности несовершеннолетних // Российский следователь. 2014. № 21. С. 9-13.

8. Бурлака С.А. Цели принудительных мер воспитательного воздействия // Российский следователь. 2013. № 5. С. 25-28.

9. Макарова C.A. Некоторые аспекты применения принудительных мер воспитательного воздействия в отношении несовершеннолетних // Вопросы ювенальной юстиции. 2014. № 4. C. 21-24.

10. Овсянников И.В., Солонина С.Ю. Установление возможности исправления несовершеннолетнего путем применения принудительных мер воспитательного воздействия // Вестник Воронежского института МВД России. 2015. № 1. С. 153-158.

11. Соловьев В.С., Тюрина И.Н. О проблемах эффективности принудительных мер воспи- 
тательного воздействия, связанных с особенностями личности несовершеннолетнего преступника // Законодательство. 2015. № 10. С. 69-75.

12. Филиппова E.O. Понятие, сущность, цели принудительных мер воспитательного воздействия // Концепт. 2016. № 3. С. 61-65.

13. Биктимеров Э.Л. Иные меры уголовно-правового характера и их роль в осуществлении задач уголовного права России: дис. ... канд. юрид. наук. Саратов, 2009.

14. Савина Т.А. Принудительные меры воспитательного воздействия в законодательстве некоторых стран Евросоюза // Вопросы ювенальной юстиции. 2015. № 2 (56). С. 16-20.

15. О новых подходах к преступности среди несовершеннолетних и о значении правосудия по делам несовершеннолетних: рекомендация Комитета министров Совета Европы от 24 сент. 2003 г. № Rec (2003) 20. URL: http://holmskiy.sah.sudrf.ru/modules.php?name=info_court\&id=37

16. Орлова Ю.Р. Повышение эффективности назначения наказания и принудительных мер воспитательного воздействия как одна из приоритетных задач формирования уголовной политики российского государства в отношении несовершеннолетних // Ученые записки Орловского государственного университета. 2013. № 5 (55). С. 189-194.

17. Щедрин Н.В., Никитина Н.А. О правовой природе и перспективах института освобождения с применением принудительных мер воспитательного воздействия // Актуальные проблемы российского права. 2013. № 8. С. 1007-1011.

18. Аносов A.B. Соучастие несовершеннолетних в преступлениях: особенности уголовной ответственности и предупреждения: дис. ... канд. юрид. наук. М., 2016.

19. Бурлака С.А. Необходим федеральный закон о принудительных мерах воспитательного воздействия // Российский следователь. 2015. № 15. С. 41-44. 